\title{
The Acceleration Strategy of Biogas Utilization in Rural Area
}

\author{
Luluk Sulistiyo Budia \\ ${ }^{a}$ Faculty of Agriculture. Merdeka University of Madiun. Indonesia.
}

\begin{abstract}
The research objective is to obtain acceleration strategy model of biogas utilization in rural areas with a systems approach. Methods of research conducted through literature review, surveys and expert systems. Analysis of acceleration strategies using hierarchy analysis process and the selection of alternative priority using the comparison method exponential. The results showed that the acceleration strategies of biogas utilization in rural areas depend on 9 important factors, namely, the first three important factors, are in sequential order the availability of raw materials, the government policy, and the the public interest. Acceleration strategy is also depend on important actor such as the governments, the community and the extension services, while the primary goal is cost savings, utilization of waste and replacing fuel wood. As an alternative priority of successive acceleration strategy is the selection of the digester, institutional, financial services and mentoring programs.
\end{abstract}

Keywords: acceleration strategies, factors, actors, goals, alternatives, biogas digester.

\section{Introduction}

Energy shortages in developed countries turned out to have an impact on developing countries such as Indonesia (Simamora, 2006). The declining of the reserve natural energy and the increasing of human needs for living force them to always make effort and innovate to solve their problem. Any effort to subtitude household energy is by developing biogas that have raw material from cattle manure (Muryanto. Et al, 2010). The biggest parts of Indonesia are rural area which have source income in form of integrated agriculture product, one of them is cattle, so the developing of Biogas is really potential. So far, Productivity and Socialization of Biogas energy in countryside have not conferred maximal product (Suriawiria. 2005). In fact, the result of the previous study shown that society's interest toward Biogas usage that having raw material from cattle manure was high reach 76,67\% (Budi dan Wardani, 2012). It implies that potency to develop Biogas in rural society is large.

\section{Material and Method}

\subsection{Frame work.}

Inadequacy of energy must be followed by an attempt to use alternative energy which available from our environs, Productivity and the application process of alternative energy source in rural society such as much agricultural extention that have to be explored.
Biogas alternative energy productions constitute one of promising alternative energy because it is cheap and regulatory readiness. That is why, needed usage acceleration to attain hope. It is not an easy job; have to formulate it accurately, it have to remain that energy is a complex problem so need all of party to participate in comprehensive and continuing system.

\subsection{Method}

The study was conducted in Madiun district in January-March 2013, the data was collected through a literature review, questionnaires and expert systems. Analysis of acceleration strategies performed using analytical hierarchy process/AHP (Saaty, 1993). Acceleration strategy includes factors, actors, objectives and alternatives. The alternatives selection using the comparison method exponential/MPE (Eryatno, 1999, Marimin, 2005). Selection of alternatives based on the criteria in the weight and then it will be obtained with exponential functions for priority score.

\subsection{Staps Activities}

The steps of the research strategy of accelerating the use of biogas in rural areas simply presented in Figure 1. 


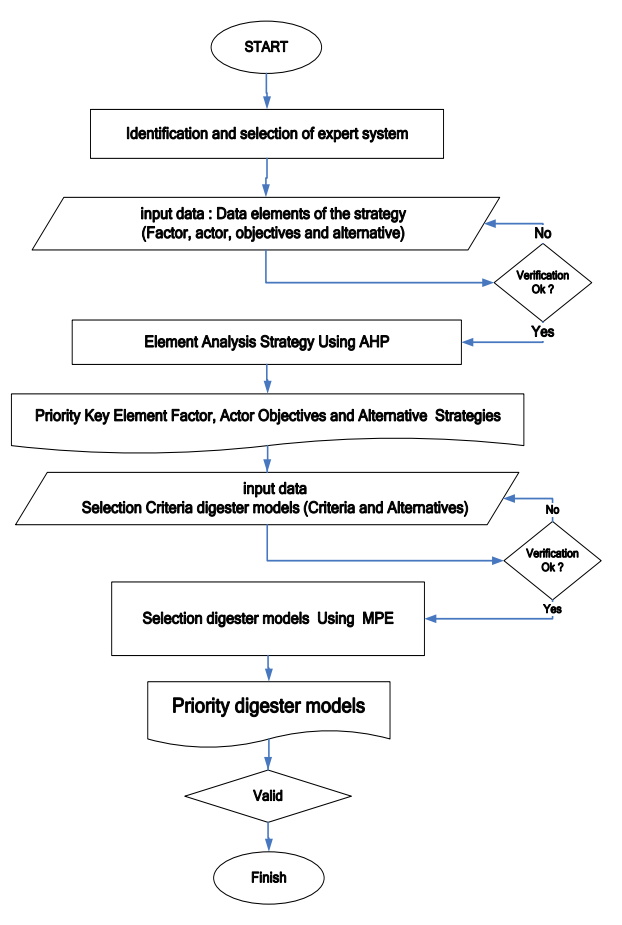

Fig. 1. Utilization of biogas flow chart accelerated

\section{Result and Discussion}

As shows in figure2, key element weight value of acceleration factors in biogas use in villages are the availability of raw material $(0.196)$, government policy (0.190), and the availability of technology (0.182). But, another elements key for developing biogas is public interest $(0.130)$. Considering the availability of raw material in villages is very abundance, and government policy which motivates, supports and binds related the use of waste to energy alternative changing should
Strategic analysis result in accelerating biogas use with system approach through factor component showed that there are nine keys elements they are; the availability of other energy, government policy, the availability of raw material, production cost, the availability of technology, public interest, the availability of worker, finance support service and institute, will be explained in Figure 2.

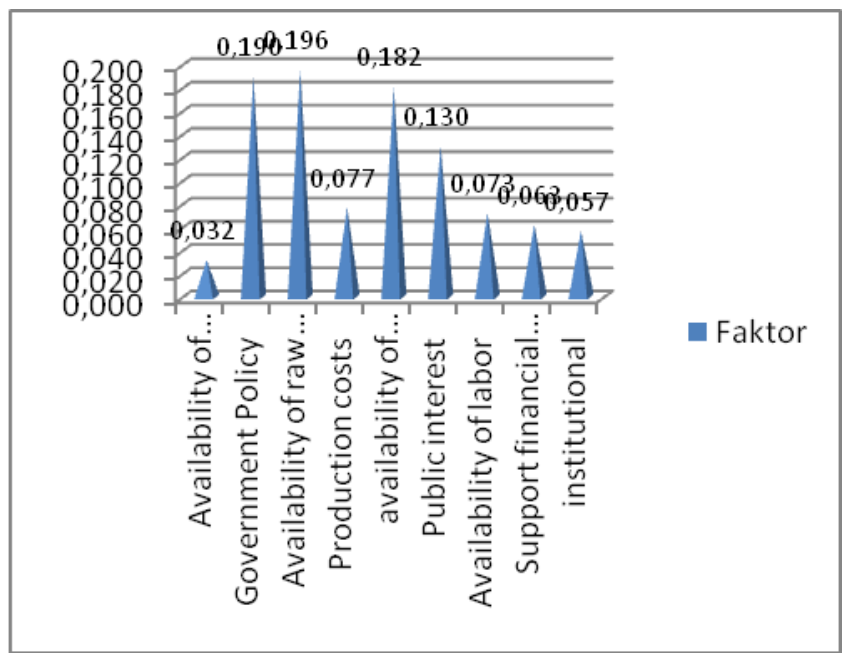

Fig. 2 The results of AHP analysis on the acceleration factor of biogas utilization

become mass movement to accelerate biogas use so the result could be achieved soon (Budi, 2012).

Analysis result of acceleration biogas use related to actor shows there are 7 prime agents consist of society prominent, extension agent, profession organization gathering, finance service, $\mathrm{R}$ and $\mathrm{D} / \mathrm{PT}$, local government (Figure 3)

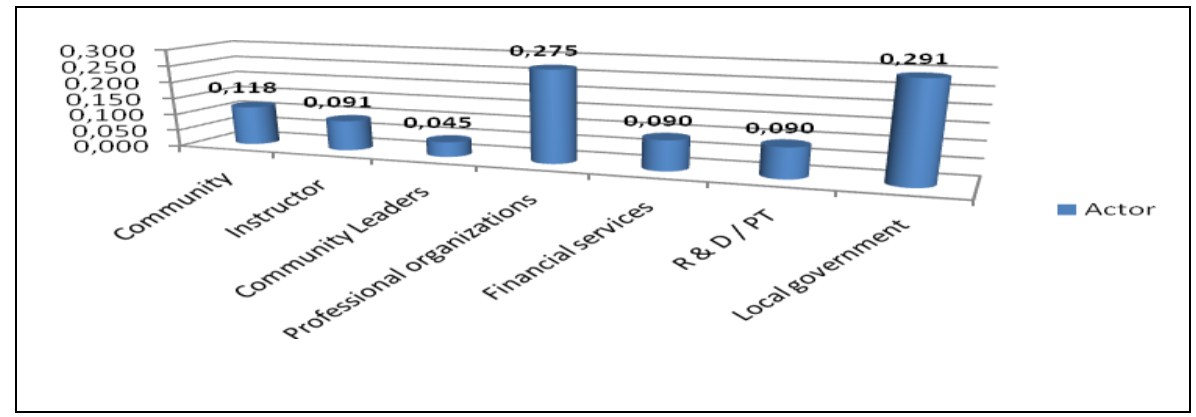

Fig. 3 The results of AHP analysis of the key actor accelerated utilization of biogas 
As seen in Figure 3, local government (0291) and profession organization (0375) have two highest weights compare another actors, it means that local

The result of biogas usage acceleration related with the purpose of program consists of 5 objective elements, there are: cost saving, waste usage, fuels substitute, raising of revenue and improving knowledge. The objective elements value will be presented in Figure 4.

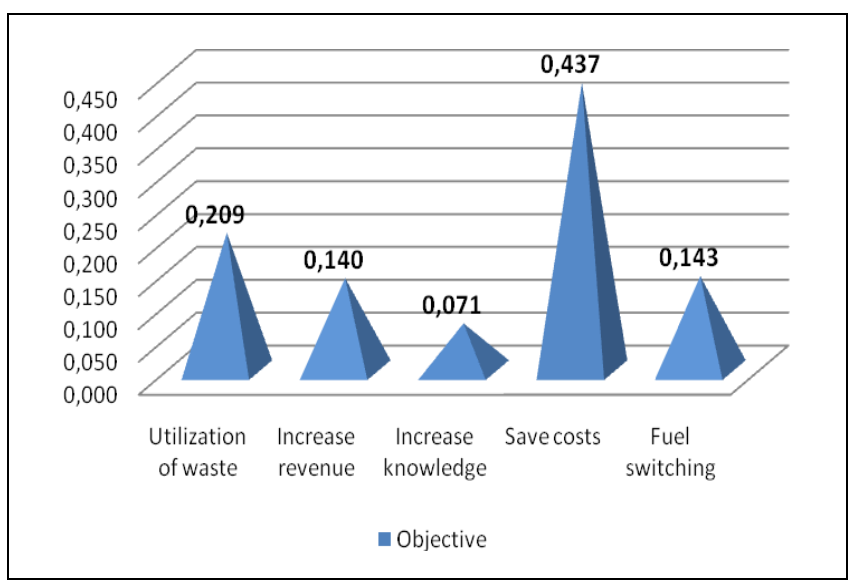

Fig 4. Results of the analysis AHP objective elements.

The result of biogas usage in rural area which have to be done in succession are digester selection, societies participation, budget, mentoring, organizations, and raw material kind. Alternative priority value will be presented in detail in Figure 5. government involvement and professional organization in acceleration biogas use are expected.

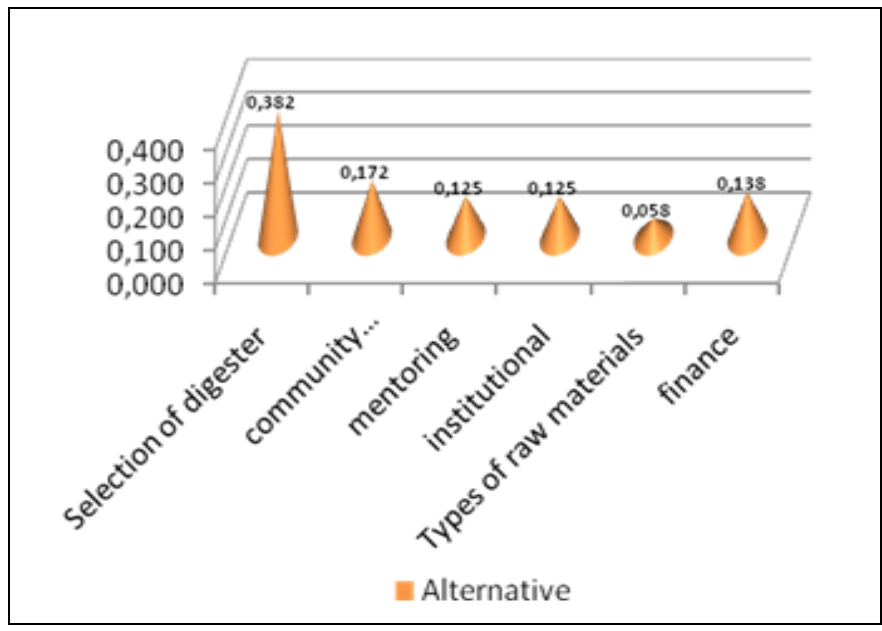

Fig 5. Results of the AHP analysis regarding the alternative that must be done.

Moreover the selection of biogas digester was done by consider some criteria, there are: process of making, maintenance convenience, process of making cost, durability level, applicability material, capacity conformance, location, and technology suitability. MPE analysis result in simple digester model, modern and semi modern, as on the following Table 1.

\begin{tabular}{|c|c|c|c|c|}
\hline \multirow{2}{*}{ Criteria } & \multirow{2}{*}{ Weight } & \multicolumn{3}{|c|}{ Alternative models of biogas digester } \\
\hline & & Simple & Modern Semi & Modern \\
\hline The process of makin & 9 & 9 & 7 & 5 \\
\hline Ease of Maintenance & 9 & 9 & 7 & 7 \\
\hline The cost of making & 9 & 9 & 7 & 5 \\
\hline Upkeep & 8 & 8 & 8 & 8 \\
\hline Level of resistance & 6 & 8 & 7 & 7 \\
\hline Compliance with raw & 6 & 7 & 7 & 7 \\
\hline Capacity flexibility & 5 & 8 & 8 & 7 \\
\hline Suitability Location & 3 & 9 & 8 & 8 \\
\hline Technological flexibilit & 7 & 8 & 8 & 7 \\
\hline \begin{tabular}{|l|l} 
Total & \\
\end{tabular} & & 852658531,9 & 136416565,3 & 42030934,17 \\
\hline Priority & & 1 & $\|$ & III \\
\hline
\end{tabular}

A seen in Table 1, simple digester model chosen as primary priority of acceleration biogas usage in rural area. 


\section{Conclusion}

Acceleration of biogas usage in rural area can be implemented if it can be done by using system approach that is optimization of government role through a motivated policy, motivate but also bond, and professional organization which can invite people to active participate so that it can change the society's mindset toward biogas energy to be a primary needs and individually earning. Besides that, the implementation of the program is done by considering cost approach, technology and availability of digester construction material, so the acceleration objective to save cost will be able achieved

\section{Acknowledgements}

The authors would like to thank the Rector of Merdeka University of Madiun who give financial support of this research and all those who have helped the implementation of this research

\section{References}

Budi and Wardani, 2012. Public Perceptions Of Biogas For Household Energy Needs, EBTKE Conex 2012

Budi, 2012. Prospek pengembangan agroindustri hortikultura di Kabupaten Madiun dengan pendekatan kelayakan finansial dan produk unggulan, prosiding seminar nasional Membangun Negara Agraris yang berkeadilan dan berbasis kearifan lokal, Fakultas Pertanian Universitas Sebelas Maret Surakarta , 18 April 2012

Eriyatno, 1999, Science Systems: Improving the Quality and Effectiveness Management. Volume one. Bogor: IPB Press

Marimin. 2005. Teori dan Aplikasi Sistem Pakar dalam Teknologi Manajerial. Bogor: IPB Press.

Muryanto, Agus Hermawan, Muntoha, Dan Widagdo 2010 Drum Biogas Plant Technology Recommendations Household scale.

Saaty TL. 1993. Pengambilan Keputusan Bagi Para Pemimpin. Proses hirarki analitik untuk pengambilan keputusan dalam situasi kompleks. Terjemahan. Jakarta: PT. Puataka Binaman Pressindo.
Simamora, S., Salundik., Wahyuni, S. dan Surajudin. 2006, Membuat Biogas Pengganti Bahan Bakar Minyak dan Gas dari Kotoran Ternak. Agromedia Pustaka. Jakarta.

Suriawiria,uh. 2005. Harvest Biogas from Waste http://www. minds of the people, cyber media. 